\title{
SYLWIA ŁAZAREWICZ
}

ORCID: 0000-0003-1950-9993

Uniwersytet Warmińsko-Mazurski w Olsztynie

\section{LEGITYMACJA ORGANÓW SPÓŁKI ORAZ ICH CZŁONKÓW DO ZASKARŻANIA UCHWAŁ ZGROMADZEŃ SPÓŁEK KAPITAŁOWYCH}

\begin{abstract}
Abstrakt: Ustawodawca przyznał legitymację do zaskarżania uchwał wspólników zarówno organom spółek kapitałowych, jak i ich poszczególnym członkom. Kodeks spółek handlowych nie precyzuje jednak ani zasad wniesienia powództwa przez zarząd, radę dyrektorów, radę nadzorczą lub komisję rewizyjną, ani kręgu uprawnionych członków tych gremiów. Głównym celem artykułu jest ustalenie, kiedy wygasa uprawnienie członków organów spółek kapitałowych do zaskarżenia uchwał wspólników. Wzgląd na ratio legis analizowanych przepisów nakazuje przyjąć, że członek organu zachowuje prawo do popierania powództwa choćby po wniesieniu pozwu utracił swój status. Za niezapewniające właściwego poziomu ochrony należy uznać również stanowisko Sądu Najwyższego odmawiające byłemu członkowi organu spółki legitymacji do zaskarżenia uchwały o jego odwołaniu oraz uchwały o nieudzieleniu mu absolutorium.

Słowa kluczowe: prawo handlowe, spółki kapitałowe, orzecznictwo Sądu Najwyższego, zaskarżanie uchwał, powództwo o stwierdzenie nieważności lub uchylenie uchwały
\end{abstract}

\section{WPROWADZENIE}

Przepisy kodeksu spółek handlowych, przewidując możliwość zaskarżenia uchwały wspólników spółki kapitałowej, określają jednocześnie listę uprawnionych do tego podmiotów. Wniesienie powództwa zarówno o uchylenie, jak i o stwierdzenie nieważności uchwały zastrzeżone jest dla tego samego kręgu legitymowanych. Stosownie do treści art. 250 i art. $422 \S 2$ oraz w związku z art. $300^{101}$ k.s.h. są to organy spółek kapitałowych, to jest zarządy i rady nadzorcze (w spółkach z ograniczoną odpowiedzialnością także komisje rewizyjne, zaś w prostych spółkach akcyjnych również rady dyrektorów) oraz poszczególni członkowie tych gremiów (art. 250 pkt 1 i art. $422 \S 2$ pkt 1 k.s.h.). Przy spełnieniu dodatkowych przesłanek legitymacja przysługuje również wspólnikom spółki (art. 250 pkt 2-5 i art. 422 $\S 2$ pkt 2-4 k.s.h.). Ustawodawca przyjął zatem wąski krąg uprawnionych do kwestionowania uchwał. Inaczej niż w przypadku powództwa o ustalenie istnienia 
lub nieistnienia stosunku prawnego lub prawa, które wnieść może każdy, kto ma w tym interes prawny (art. 189 k.p.c.).

Legitymacja do zaskarżania uchwał wspólników, w którą wyposażono zarówno organy spółki in gremio, jak i ich indywidualnych członków, nie jest uzależniona od spełnienia jakichkolwiek dodatkowych wymagań. Pomimo klarownego brzmienia przepisów w tym zakresie, zarówno wskazany krąg uprawnionych nie został precyzyjnie zakreślony, jak i same zasady wniesienia powództwa nie są do końca jasne. Korzystanie z przyznanych uprawnień przez organy spółki wymaga bowiem ustalenia zarówno zasad podjęcia decyzji o zaskarżeniu uchwały, jak i samego sposobu wniesienia pozwu. Jeśli chodzi o legitymację poszczególnych członków organów, niezbędnym jest zaś określenie, kiedy wygasa uprawnienie do zaskarżenia uchwały. Tym samym uzyskamy odpowiedź na pytanie o możliwość kontynuacji postępowania, w trakcie którego skarżący zostaje odwołany z funkcji piastuna organu. Zdecydowanie największe wątpliwości budzi jednak kwestia legitymacji do zaskarżania uchwał przez byłych członków organów spółki, zwłaszcza w odniesieniu do decyzji tak newralgicznych, jak uchwała o odwołaniu z funkcji i uchwała o nieudzieleniu absolutorium.

Poszukując odpowiedzi na tak postawione pytania, niezbędnym jest odniesienie się do celu i przyczyny przyznania organom spółki oraz ich poszczególnym członkom legitymacji do zaskarżania uchwał wspólników. Tym bardziej, że doprecyzowując katalog uprawnionych — do takowego uzasadnienia odwołuje się w swoim orzecznictwie również Sąd Najwyższy.

\section{LEGITYMACJA ORGANÓW SPÓŁKI ORAZ ICH CZŁONKÓW DO ZASKARŻANIA UCHWAŁ WSPÓLNIKÓW}

\subsection{LEGITYMACJA ORGANÓW SPÓŁKI IN CORPORE}

Zgodnie z brzmieniem przepisów art. 250 pkt 1 i art. $422 \S 2$ pkt 1 k.s.h. legitymowani do wytoczenia powództwa o stwierdzenie nieważności lub uchylenie uchwały wspólników są: zarząd, rada nadzorcza, komisja rewizyjna oraz poszczególni ich członkowie. Natomiast w myśl art. $300^{101}$ k.s.h., który nakazuje odpowiednie stosowanie przepisów art. 422-427 k.s.h. do uchwał akcjonariuszy prostej spółki akcyjnej, przyjąć należy, że wskazaną legitymację posiadają również rada dyrektorów oraz poszczególni członkowie tego organu".

Norma o uprawnieniu organów spółki do zaskarżania uchwał wspólników wzbudza jednak wątpliwości co do reguł, w oparciu o które wytaczają one takie powództwo. W tym wypadku organy nie działają bowiem za spółkę (zwłaszcza że jest ona przeciwną stroną sporu), ale we własnym imieniu. Tym samym zasadne jest ustalenie sposobu ich reprezentacji.

W doktrynie przedstawiono dwa przeciwstawne stanowiska dotyczące tej kwestii. W myśl pierwszego z nich, wniesienie przez organ powództwa o uchylenie 
lub stwierdzenie nieważności uchwały wspólników odbywa się zgodnie z przyjętymi w kodeksie spółek handlowych zasadami. W przypadku powództwa zarządu lub rady dyrektorów powinna zatem poprzedzać je stosowna uchwała tegoż organu, a sposób reprezentacji wynikać z art. 205, art. $300^{66}$ (lub art. $300^{78}$ ) i art. 373 k.s.h. Podstawą działania rady nadzorczej (w spółce z o.o. także komisji rewizyjnej) powinien być natomiast jej regulamin ${ }^{1}$.

Pamiętać jednak należy, że przepisy art. 250 pkt 1 i art. $422 \S 2$ pkt 1 k.s.h. przyznają organom spółki zdolność do występowania z powództwem przeciwko spółce. Choć nie wprowadzają one uregulowań co do sposobu ich działania w takiej roli, to należy przyjąć, że zasady odnoszące się do ogólnej reprezentacji spółki, nie znajdują tu zastosowania. Dotyczą one bowiem działania za spółkę, a nie autonomicznego działania organu jako strony procesu ${ }^{2}$. Zarówno zarząd, jak i rada nadzorcza (w spółce z o.o. także komisja rewizyjna, zaś w prostej spółce akcyjnej także rada dyrektorów) powinny podjąć uchwałę o wystąpieniu z powództwem ${ }^{3}$. By wszystkie osoby wchodzące w skład organu nie musiały działać łącznie, możliwe, a nawet pożądane jest wskazanie w uchwale jednego z członków jako uprawnionego do podejmowania czynności w ramach procesu bądź też po prostu udzielenie pełnomocnictwa procesowego ${ }^{4}$. Taki właśnie sposób działania organu in gremio należy uznać za właściwy przy korzystaniu z uprawnień do zaskarżenia uchwały wspólników spółki kapitałowej.

\subsection{LEGITYMACJA CZŁONKÓW ORGANÓW SPÓŁKI}

Poszczególni funkcjonariusze spółki są uprawnieni do zaskarżania uchwał bez konieczności spełnienia dodatkowych przesłanek wymaganych w takiej sytuacji od wspólników. W konsekwencji udziałowców i akcjonariuszy będących jednocześnie członkami organu spółki nie dotyczą ograniczenia wymienione

1 J.P. Naworski, [w:] Kodeks spółek handlowych. Komentarz, t. 3, red. T. Siemiątkowski, R. Potrzeszcz, Warszawa 2013, s. 992; A. Kidyba, Kodeks spółek handlowych, t. 1. Komentarz do art. 1-300 k.s.h., Warszawa 2013, s. 1153; P. Gierat, Zaskarżanie uchwat zgromadzeń spółek kapitałowych przez ich organy oraz przez członków tych organów, „Monitor Prawniczy” 2008, nr 13, s. 679.

2 R. Pabis, [w:] Kodeks spótek handlowych, Tom 2B. Spótka z ograniczoną odpowiedzialnością. Komentarz. Art. 227-300, red. A. Opalski, Warszawa 2018, art. 250, nb 11.

3 Za koniecznością działania organu in corpore, ale brakiem obowiązku podjęcia uchwały o wyrażeniu zgody na wytoczenie powództwa o zaskarżenie uchwały wspólników, opowiadają się E. Marszałkowska-Krześ, M. Jagodziński, Występowanie organów spółek kapitałowych na podstawie przepisów przyznających szczególna zdolność sądowa w sprawach o zaskarżenie uchwat zgromadzeń tych spótek — rozważania de lege lata oraz de lege ferenda, [w:] Kodeks spótek handlowych po piętnastu latach obowiazywania, red. J. Frąckowiak, Warszawa 2018, s. 520-522.

${ }^{4}$ M. Chomiuk, [w:] Kodeks spółek handlowych. Komentarz, red. Z. Jara, Warszawa 2020, art. $250, \mathrm{nb} 6$. 
w art. 250 pkt $2-5$ i art. $422 \S 2$ pkt 2-4 k.s.h., gdyż źródłem ich legitymacji jest sam fakt zasiadania $w$ organie ${ }^{5}$.

Funkcjonariusz spółki uprawniony jest do zaskarżenia uchwały wspólników, choćby został powołany po jej powzięciu ${ }^{6}$. Spory doktrynalne budzi jednak utrata statusu przez piastuna organu w trakcie toczącego się już przed sądem postępowania. Przewidziane w art. 250 i art. $422 \S 2$ k.s.h. prawo do żądania uchylenia uchwały lub stwierdzenia jej nieważności stanowi legitymację czynną w znaczeniu materialnoprawnym. Zgodnie z art. $316 \S 1$ k.p.c. sąd, wydając wyrok, bierze za podstawę stan rzeczy istniejący w chwili zamknięcia rozprawy. Zdaniem niektórych przedstawicieli nauki to ten moment powinien być zatem decydujący dla oceny legitymacji powoda, a nie stan istniejący w chwili podejmowania czy skarżenia uchwały ${ }^{7}$. W odniesieniu do wspólników spółki pogląd, że warunkiem zaskarżenia uchwały jest posiadanie statusu wspólnika w chwili, gdy uchwała była podejmowana, $\mathrm{w}$ dacie wniesienia pozwu, a także $\mathrm{w}$ dacie wyrokowania przyjął również SN w uzasadnieniu orzeczenia z 7 lutego $2006 \mathrm{roku}^{8}$.

Wzgląd na okoliczność, że skarżący uchwałę członek organu działa w interesie spółki nakazuje jednak przyjąć, że nie traci on legitymacji w razie wygaśnięcia jego mandatu w trakcie procesu. To do byłego piastuna organu powinna należeć decyzja, czy pomimo utraty funkcji będzie dalej popierał powództwo ${ }^{9}$. Tym samym należy zaaprobować pogląd obecny również w piśmiennictwie, że utrata członkostwa w organie po zaskarżeniu uchwały pozostaje bez znaczenia, mogłaby bowiem skutkować niedopuszczaniem do sądowej kontroli uchwał poprzez odwoływanie skarżących ${ }^{10}$. Tak też wypowiedział się SA w Warszawie, przyjmując w wyroku z 12 czerwca 2003 roku $^{11}$, że ,chwila wytoczenia powództwa jest elementem rozstrzygającym o istnieniu legitymacji czynnej do wytoczenia powództwa na bazie art. 250 pkt 1 k.s.h. o uchylenie uchwały niezależnie od tego, czy w jego toku nastąpiły zmiany w składzie danego organu”.

5 Z. Kwaśniewski, Zaskarżanie uchwat zgromadzeń spółek kapitałowych - problem legitymacji czynnej, [w:] Kodeks spótek handlowych po pięciu latach, red. L. Banel, U. Gączkowska, Wrocław 2006, s. 722; P. Gierat, op. cit., s. 679.

${ }^{6}$ R. Pabis, Kodeks spótek handlowych..., art. 250, nb 7; K. Bilewska, [w:] Kodeks spótek handlowych. Komentarz, red. Z. Jara, Warszawa 2020, art. 422, nb 27.

7 J.P. Naworski, op. cit., s. 996-997; K. Bilewska, Kodeks spótek handlowych..., op. cit.; A. Jarocha, Powództwo o stwierdzenie nieważności uchwały wspólników spótki kapitałowej, Toruń 2010, s. 244.

8 Wyrok SN z 7 lutego 2006 roku, IV CSK 41/05, OSP 2006/9/108.

9 R. Pabis, Kodeks spótek handlowych..., art. 250, nb 14.

10 J. Szwaja, [w:] S. Sołtysiński et al., Kodeks spótek handlowych, t. 3. Komentarz do artykutów 301-490, Warszawa 2013, s. 1389-1390; A. Pęczyk-Tofel, Legitymacja czynna na gruncie art. 250 i art. 422 \& 2 k.s.h., „Prawo Spółek” 2007, nr 10, s. 30; M. Rodzynkiewicz, Kodeks spółek handlowych. Komentarz, Warszawa 2013, s. 467.

11 Wyrok SA w Warszawie z 12 czerwca 2003 roku, I ACa 1609/02, LEX nr 1681332. 


\section{LEGITYMACJA BYŁYCH CZŁONKÓW ORGANÓW SPÓŁKI DO ZASKARŻANIA UCHWAŁ WSPÓLNIKÓW}

\subsection{PRZEGLĄD STANOWISK DOKTRYNY I JUDYKATURY}

Kwestią, która wywołała liczne polemiki wśród przedstawicieli doktryny prawa $^{12}$ i (przynajmniej do czasu) była przedmiotem poważnych rozbieżności w orzecznictwie, jest dopuszczalność zaskarżania uchwał wspólników przez byłych członków organów spółki.

Spośród wielu argumentów podnoszonych przez zwolenników odmowy byłemu funkcjonariuszowi spółki prawa do kwestionowania uchwał wspólników należy wymienić przede wszystkim ten wynikający z wykładni językowej. Treść art. 250 pkt 1 i art. $422 \S 2$ pkt 1 k.s.h. wskazuje, że wyłącznie aktualni (urzędujący) funkcjonariusze spółki są uprawnieni do wniesienia powództwa o uchylenie lub stwierdzenie nieważności uchwały.

Zwolennicy stanowiska, że legitymacja nie przysługuje osobom niebędącym już we władzach spółki wywodzą swój pogląd również z przyjęcia, że określony $\mathrm{w}$ art. $250 \mathrm{i}$ art. $422 \S 2$ k.s.h. katalog podmiotów ma charakter zamknięty. Tym samym niemożliwe jest dokonywanie jego wykładni rozszerzającej ${ }^{13}$. W konsekwencji zaprzestanie pełnienia funkcji we władzach spółki (bez względu na przyczynę) jest równoznaczne $\mathrm{z}$ utratą prawa do zaskarżania uchwał jej wspólników. $\mathrm{Z}$ wygaśnięciem mandatu wygasają bowiem prawa i obowiązki członka organu spółki, w tym również prawo do podważania uchwal ${ }^{14}$.

Znaczenie dla przyjęcia omawianego stanowiska mają również argumenty celowościowe. Ratio legis przepisów dotyczących zaskarżania uchwał wspólników opiera się na założeniu, że pewność obrotu prawnego z udziałem spółek kapitałowych wymaga ograniczenia możliwości kwestionowania decyzji wspólników do określonego kręgu podmiotowego, przesłanek i terminów zaskarżenia ${ }^{15}$.

Z kolei przeciwnicy takiego poglądu wskazywali, że sama konstrukcja spółek kapitałowych przemawia za przyznaniem byłemu piastunowi organu legitymacji czynnej do zaskarżania uchwał wspólników. Niejednokrotnie mogą oni być jedynymi osobami, które są w stanie uniemożliwić naruszenie interesu spółki, jej

12 Poglądy wyrażone do momentu podjęcia uchwały składu siedmiu sędziów SN (zasada prawna) z 1 marca 2007 roku, III CZP 94/06, OSNC 2007/7-8/95 zebrała M. Czajkowska-Dąbrowska, Konsekwencje sprzeczności z prawem uchwat zgromadzeń wspólników spótek kapitałowych ze szczególnym uwzględnieniem legitymacji byłych członków organów spółek do zaskarżania tych uchwat, [w:] Studia i analizy Sądu Najwyższego, t. 1, red. K. Ślebzak, Warszawa 2007, s. 55 n.

13 Z. Kwaśniewski, op. cit., s. 725.

14 P. Gierat, op. cit., s. 685; Z. Kuniewicz, Glosa do wyroku SN z 11 stycznia 2002 r., IV CKN 1503/00, „Orzecznictwo Sądów Polskich” 2003, nr 2, poz. 21.

${ }^{15} \mathrm{~K}$. Bilewska, Zaskarżanie uchwat zgromadzenia wspólników przez odwołanych członków organów spótki. Glosa do uchwaty SN (7) z 21.3.2007 r., III CZP 94/06, „Monitor Prawniczy” 2007, nr 19, s. 1097. 
wierzycieli czy poszczególnych grup wspólników ${ }^{16}$. Interes spółki może różnić się od interesu wspólników, którzy nie akceptując decyzji zarządu, na mocy uchwały odwołają jego członków. Wówczas jedynymi osobami zainteresowanymi podważeniem takiej uchwały będą byli już funkcjonariusze spółki. Pozbawienie ich tego prawa może skutkować pozostaniem wadliwej uchwały w obrocie ${ }^{17}$.

Potwierdzeniem wskazanych rozbieżności były przeciwstawne judykaty, w których albo odmawiano byłym członkom organów spółki prawa do zaskarżania uchwał wspólników, albo przyznawano im to prawo, choć najczęściej nie poprzez uznanie generalnej kompetencji, lecz wskazanie spraw, których rozstrzygnięcie były funkcjonariusz spółki może zaskarżyć.

Zasadniczo nie budzi większych wątpliwości, że po stronie skutecznie odwołanego piastuna organu spółki lub takiego, którego mandat wygasł wskutek upływu kadencji bądź rezygnacji, brak jest generalnego prawa do podważania uchwał wspólników tej spółki. Tak przyjmowano w judykaturze już na gruncie kodeksu handlowego ${ }^{18}$, podnosząc, że byli członkowie organów są uprawnieni do wniesienia powództwa jedynie wtedy, gdy nadal pozostają wspólnikami spółki. Uznać, że odwołany piastun zaskarża uchwałę w interesie spółki można tylko wówczas, gdy nadal pozostaje on jej wspólnikiem.

Podobnie - na gruncie kodeksu spółek handlowych — konstatował SN w uzasadnieniu uchwały z 17 lutego 2004 roku $^{19}$. Odnosząc się do prawa do wytoczenia powództwa o stwierdzenie nieważności uchwały wspólników sprzecznej z ustawą wskazywał, że ,skoro przepis art. 250 pkt 1 k.s.h. stanowi, że prawo to przysługuje członkom organów spółki, a więc także członkom zarządu spółki, to lege non distinguente uprawnienie to nie może przysługiwać osobom, które skutecznie zostały odwołane ze składu zarządu”. Co więcej, stwierdzał, że pozbawienie byłych menadżerów prawa do zaskarżenia uchwały wspólników również nie jest przyzwoleniem na usuwanie tak zwanych krnąbrnych członków zarządu,

16 W. Jurcewicz, Zaskarżanie uchwat przez odwołanych członków zarządu spótki. Glosa do wyroku SN z 11.01.2002 r., IV CKN 1503/00, „Przegląd Prawa Handlowego” 2003, nr 3, s. 57; idem, Legitymacja czynna członków władz spótki do zaskarżenia uchwał zgromadzenia wspólników. Glosa do uchwały składu siedmiu sędziów SN z 1.03.2007 r., III CZP 94/06, „Glosa” 2008, nr 1, s. 45; S. Sołtysiński, W. Popiołek, Legitymacja czynna odwołanych członków władz spótki do zaskarżenia uchwat sprzecznych z ustawa, „Przegląd Prawa Handlowego” 2007, nr 10, s. 56; A. Pęczyk-Tofel, op. cit., s. 36; S. Szajkowski, M. Tarska, [w:] S. Sołtysiński et al., Kodeks spółek handlowych, t. 2. Komentarz do artykułów 151-300, Warszawa 2014, s. 704-705.

17 M.J. Skrodzka, K. Skrodzki, Legitymacja czynna byłego członka zarzadu spótki z o.o. do zaskarżenia uchwat wspólników - w świetle poglądów doktryny i orzecznictwa, „,Monitor Prawniczy" 2007, nr 19, s. 1067.

18 Wyrok SN z 14 lipca 1994 roku, I CRN 75/94, LEX nr 138643; wyrok SN z 31 stycznia 1997 roku, II CKN 68/96, LEX nr 1635222; wyrok SN z 11 stycznia 2002 roku, IV CKN 1503/00, OSNC 2002/11/136.

19 Uchwała SN z 17 lutego 2004 roku, III CZP 116/03, OSNC 2005/5/78. 
ponieważ „odwoływanie członków zarządu wynika z uregulowań ustawowych (art. 203 k.s.h.); można to prawo wprawdzie ograniczyć, ale nie można wyłączyć”". W wyroku z 7 lutego 2006 roku $^{20}$ SN powtórzył, że

przepis art. $422 \S 2$ k.s.h. ma charakter formalny, musi być traktowany rygorystycznie i wykładany ściśle, a wyliczenie w nim podmiotów oraz przypadków, w których te podmioty są uprawnione do zaskarżenia uchwały, należy uznać za wyczerpujące. [...] Przyznanie członkom organów prawa do kwestionowania uchwał wspólników nastąpiło wyłącznie ze względu na pełnione przez nich funkcje i miało na celu umożliwienie organom spółki działania w interesie spółki i wszystkich akcjonariuszy [...]. Utrata statusu członka zarządu lub rady eliminuje przyczyny, dla których przyznano im legitymację do zaskarżania uchwał i powoduje utratę tej legitymacji.

Bogate orzecznictwo dotyczące legitymacji byłych członków organów spółki do kwestionowania uchwał jej wspólników wieńczy uchwała SN (7) z 1 marca $2007 \mathrm{roku}^{21}$. Jej teza stanowi o braku legitymacji osoby odwołanej ze składu organu spółki z ograniczoną odpowiedzialnością do wytoczenia powództwa o stwierdzenie nieważności uchwały wspólników sprzecznej z ustawą. Ze względu na nadaną moc zasady prawnej rozstrzygnięcie ma oczywisty wpływ na linię orzeczniczą. Odstąpienie przez jakikolwiek skład Sądu Najwyższego od tak sformułowanej zasady wymaga przedstawienia powstałego zagadnienia prawnego do rozstrzygnięcia pełnemu składowi izby.

Przyjęte rozumowanie potwierdził wyrok TK z 2 czerwca 2009 roku $^{22}$, uznający, że odmowa przyznania odwołanemu członkowi zarządu legitymacji do wytoczenia powództwa o uchylenie uchwały o nieudzieleniu absolutorium pozostaje w zgodzie z zagwarantowanym w art. 45 Konstytucji RP prawem do sądu, to jest uprawnieniem każdego podmiotu do rozstrzygnięcia przez sąd dotyczących go kwestii mających znaczenie prawne. Ustawodawca może bowiem w określonych sytuacjach upoważniać tylko pewne osoby do występowania z oznaczonymi powództwami, a inne tego uprawnienia pozbawiać. Na takiej zasadzie opiera się konstrukcja legitymacji czynnej.

Uznając rangę i znaczenie praktyczne uchwały składu siedmiu sędziów SN z 1 marca 2007 roku, należy opowiedzieć się jednak za stanowiskiem odmiennym w odniesieniu do dwóch newralgicznych uchwał wspólników, to jest do uchwały o odwołaniu członka organu oraz uchwały o nieudzieleniu mu absolutorium, a tym samym za możliwością przyznania byłemu piastunowi uprawnienia do zaskarżenia uchwał wspólników dotyczących lub kształtujących jego prawa i obowiązki.

20 Wyrok SN z 7 lutego 2006 roku, IV CSK 41/05, OSP 2006/9/108.

${ }^{21}$ Uchwała składu siedmiu sędziów SN (zasada prawna) z 1 marca 2007 roku, III CZP 94/06, OSNC 2007/7-8/95.

${ }^{22}$ Wyrok TK z 2 czerwca 2009 roku, SK 31/08, Dz.U. nr 91, poz. 752. 


\subsection{LEGITYMACJA BYŁEGO CZŁONKA ORGANU SPÓŁKI DO ZASKARŻENIA UCHWAŁY O JEGO ODWOŁANIU}

W piśmiennictwie wskazuje się, że za brakiem uprawnienia byłego członka organu do zaskarżenia uchwały w przedmiocie swojego odwołania przemawia ratio legis regulacji, którym jest ochrona praw spółki oraz jej uczestników. Nie mieści się w nim zaś ochrona interesów prawnych odwołanego funkcjonariusza.

Wspólnicy mają prawo swobodnie kształtować skład organów spółki. Nie można narzucać spółce osoby, która ma być piastunem organu, jeżeli nikt poza nią nie jest tym zainteresowany ${ }^{23}$. Przyjęcie, że odwołany członek organu jest legitymowany by wykazywać, że uchwała odwołująca go narusza prawo, destabilizowałoby spółkę. Wszczęcie postępowania sądowego powoduje bowiem stan niepewności, który nie sprzyja prawidłowemu funkcjonowaniu spółki. Gdy zaś sąd stwierdzi sprzeczność z ustawą uchwały odwołującej z organu, powrót piastuna i tak ograniczony jest właściwie do momentu podjęcia kolejnej, prawidłowej już uchwały ${ }^{24}$.

Poglądy takie trudno jednak zaakceptować. Odwołanie członka organu z pełnionej funkcji powinno następować $\mathrm{w}$ wyniku prawidłowo i zgodnie $\mathrm{z}$ prawem podejmowanych uchwał. Nie można uznać za przekonujący argumentu sprowadzającego się w istocie do stwierdzenia, że nawet jeśli nie zachowano wymogów ustawy, to i tak odwołanie członka organu jest tylko kwestią czasu, jeśli taka jest wola wspólników. Takie stanowisko oznacza akceptację dla bezprawia korporacyjnego i metody „faktów dokonanych" 25 . Zatem to właśnie bezpieczeństwu obrotu i jego pewności, w tym stabilizacji stosunków w spółce, zagraża przyzwolenie na podejmowanie uchwał bez poszanowania obowiązujących reguł. Odwołany członek organu powinien być wówczas uprawniony do zakwestionowania wadliwej decyzji jak nikt inny.

Ponadto argumentacja zawarta w uchwale SN z 1 marca 2007 roku, że odwołanie z funkcji wyłącza obowiązek troszczenia się przez funkcjonariusza spółki o jej interes, bowiem troska ta powinna stać się udziałem aktualnych piastunów, pomija fakt, że organy spółek kapitałowych nie muszą cechować się homogenicznym składem. Odwołanie może być bowiem wymierzone między innymi we wspólników mniejszościowych, którzy nie uczestniczyli w zgromadzeniu i tym samym nie mają legitymacji do zaskarżenia uchwały. Teza o braku uprawnienia również po stronie odwołanego piastuna organu oznacza wówczas przyzwolenie na naruszanie interesów uprawnionych ${ }^{26}$.

23 M. Chomiuk, op. cit., art. 250, nb 9.

24 P. Gierat, op. cit., s. 681.

25 W. Jurcewicz, Legitymacja czynna członków..., s. 45.

26 A. Opalski, Kodeks spółek handlowych w ostatnich latach - tendencje w orzecznictwie sądowym, [w:] Kodeks spótek handlowych po dziesięciu latach, red. J. Frąckowiak, Wrocław 2013, s. 27. 
Tym samym należy przyjąć, że to właśnie argumenty funkcjonalne przemawiają za uprawnieniem byłego członka organu do wytoczenia powództwa o stwierdzenie nieważności lub uchylenie uchwały go odwołującej. Celem art. 252 i 249 k.s.h. oraz odpowiednio art. 425 i 422 k.s.h. jest bowiem zapewnienie funkcjonowania spółki zgodnego z prawem, umową spółki i dobrymi obyczajami. Ponadto wskazane regulacje chronią interes spółki, ale mogą również chronić interesy osób uprawnionych do zaskarżania uchwał, jak choćby interesy majątkowe wspólników ${ }^{27}$.

W dyskusji dotyczącej przyznania byłym funkcjonariuszom spółki legitymacji do kwestionowania sprzecznych z prawem uchwał, na podstawie których to odwołanie nastąpiło, wskazywano również na argument związany z charakterem sankcji zastosowanej w odniesieniu do uchwał wspólników sprzecznych z ustawą. Choć kwestia ta dla praktyki obrotu została przesądzona w uchwale składu siedmiu sędziów SN z 18 września 2013 roku $^{28}$, to nadal wątpliwości dogmatyczne budzi pogląd o konstytutywnym charakterze wyroku stwierdzającego nieważność sprzecznej z ustawą uchwały wspólników spółki kapitałowej. Przyjęcie odmiennego stanowiska, to jest, że wyrok stwierdzający nieważność uchwały wspólników ma charakter deklaratoryjny, pozwalałoby uznać, że członek organu w ogóle nie był odwołany i nadal miał legitymację czynną w chwili wniesienia powództwa o stwierdzenie nieważności sprzecznej z ustawą uchwały o swoim odwołaniu ${ }^{29}$. Taki pogląd wyrażony został we wcześniejszym orzecznictwie Sądu Najwyższego, gdzie wskazano, że „,członkom zarządu przysługuje legitymacja czynna do zaskarżenia uchwały wspólników po ich »odwołaniu« w sytuacji, gdy uchwała o takiej treści stoi w sprzeczności z ustawą i jest nieważna od chwili jej podjęcia"30.

W doktrynie prawa prezentowane są nawet dalej idące głosy o uprawnieniu odwołanego członka organu do zaskarżenia również i innych uchwał powziętych na zgromadzeniu, na którym doszło do jego odwołania ${ }^{31}$, a nawet wszystkich uchwał, które zostały podjęte w okresie sprawowania przezeń mandatu. Brzmienie przepisów nie daje bowiem podstaw do wyróżnienia sytuacji, w której byli członkowie organów byliby uprawnieni wyłącznie do zaskarżenia uchwał o odwołaniu ich z funkcji oraz uchwał o odmowie udzielenia im absolutorium ${ }^{32}$.

27 M. Bieniak, [w:] J. Bieniak et al., Kodeks spółek handlowych. Komentarz, Warszawa 2020, art. 422, nb 14.

${ }^{28}$ Uchwała składu siedmiu sędziów SN z 18 września 2013 roku, III CZP 13/13, OSNC 2014/3/23.

29 B. Draniewicz, Legitymacja do wytoczenia powództwa przeciwko spótce. Glosa do uchwaty SN z 17.02.2004 r., III CZP 116/03, „Prawo Spółek” 2005, nr 5, s. 55; W. Jurcewicz, Zaskarżanie uchwat przez odwotanych..., s. 57-58.

30 Tak wyrok SN z 31 marca 2006 roku, IV CSK 46/05, LEX nr 277843.

31 Tak R. Pabis, Kodeks spótek handlowych..., art. 250, nb 25.

32 M. Bieniak, op. cit., art. 422, nb 14. 


\subsection{LEGITYMACJA BYŁEGO CZŁONKA ORGANU SPÓŁKI DO ZASKARŻENIA} UCHWAŁY O NIEUDZIELENIU MU ABSOLUTORIUM

Przyznanie uprawnienia do zaskarżenia uchwały o odmowie udzielenia absolutorium członkom organów spółki odwołanym jeszcze przed podjęciem takiej uchwały uzasadniano w judykaturze względami celowościowymi. Podnoszone były przy tym argumenty związane zarówno $\mathrm{z}$ ochroną dóbr osobistych, jak i ochroną piastunów organów przed odpowiedzialnością wobec spółki.

Udzielenie absolutorium stanowi zatwierdzenie sposobu sprawowania funkcji przez członków organów spółek kapitałowych. Choć ocena pracy funkcjonariusza spółki powinna być uczciwa, to w praktyce nie należą do rzadkości przypadki nieudzielania absolutorium przy braku obiektywnych przesłanek do odmowy skwitowania $^{33}$. Pomimo tego, że decyzja zgromadzenia jest uznaniowa, to uznaniowość nie oznacza jednak dowolności ${ }^{34}$. Wspólnikom przysługuje wprawdzie margines swobody, ale ich decyzja w przedmiocie absolutorium nie powinna być pozbawiona podstaw faktycznych. Jak słusznie wskazał SN w wyroku z 19 października 2012 roku $^{35}$, „dyskrecjonalizm decyzyjny wspólników nie może oznaczać niekontrolowanej arbitralności w zakresie oceny działalności członka zarządu”.

Jeżeli uchwala o nieudzieleniu absolutorium została podjęta z pominięciem lub wbrew faktom wynikającym ze sprawozdań rocznych, można przyjąć, że dobra osobiste członka organu zostały naruszone ${ }^{36}$. W wyroku z 29 grudnia 2016 roku SA w Warszawie wskazał, że ,uchwała walnego zgromadzenia akcjonariuszy w przedmiocie odmowy udzielenia absolutorium może prowadzić do naruszenia czci osoby, której dotyczy" ${ }^{\prime 3}$. Nieudzielenie skwitowania może bowiem narazić piastuna organu na utratę dobrego imienia, a tym samym zaufania potrzebnego do wykonywania zawodu oraz naruszyć jego poczucie własnej wartości. Jeżeli taka decyzja pozbawiona jest merytorycznych podstaw, to stanowi bezprawne naruszenie dobra osobistego ${ }^{38}$.

Ochrony przewidzianej w przepisach art. 23-24 k.c. nie można jednak uznać za wystarczającą. Postępowanie prowadzone na podstawie wskazanych regulacji umożliwia domaganie się złożenia odpowiedniego oświadczenia, zasądzenia zadośćuczynienia lub zapłaty odpowiedniej sumy na wskazany cel społeczny, nie doprowadzi jednak do wyeliminowania z obrotu prawnego uchwały o nieudzieleniu

33 D. Wajda, Naruszanie dóbr osobistych członków organów spółek kapitałowych uchwała zgromadzenia dotyczaca absolutorium, „Przegląd Prawa Handlowego” 2018, nr 11, s. 5.

${ }^{34}$ M. Romanowski, Absolutorium w spótce kapitałowej, „Przegląd Prawa Handlowego” 2002, nr 1 , s. 26 .

35 Wyrok SN z 19 października 2012 roku, V CSK 439/11, LEX nr 1238145.

${ }^{36} \mathrm{~K}$. Bilewska, Naruszenie dóbr osobistych w uchwale walnego zgromadzenia dotyczacej absolutorium, „Palestra” 2006, nr 7-8, s. 285.

37 Tak wyrok SA w Warszawie z 29 grudnia 2016 roku, VI ACa 1012/15, LEX nr 2274108.

38 B. Ostrzechowski, Naruszenie czci w wyniku nieudzielenia absolutorium w spółce kapitałowej, „Przegląd Prawa Handlowego” 2018, nr 8, s. 34. 
mu absolutorium. Przepisy o ochronie dóbr osobistych są podstawą dla roszczeń o usunięcie skutków takiej uchwały, nie mogą jednak stanowić alternatywnej drogi do eliminowania uchwał wspólników ${ }^{39}$. Tym samym, pomimo istnienia środków ochrony przewidzianych w kodeksie cywilnym, pożądane jest, by uchwała bezzasadnie odmawiająca udzielenia absolutorium mogła zostać usunięta z obrotu w drodze powództwa $z$ art. $252 \S 1$ lub art. $249 \S 1$ k.s.h. i odpowiednio art. 425 $\S 1$ lub art. $422 \S 1$ k.s.h. ${ }^{40}$

Możliwość zaskarżenia uchwały w przedmiocie absolutorium istnieje wówczas, gdy uchwała taka w ogóle została podjęta, to jest gdy wymagana bezwzględna większość głosów została oddana za uchwałą o nieudzieleniu absolutorium. Poza zakresem analizy należy pozostawić problematykę tak zwanych uchwał negatywnych, to jest dopuszczalności przyjęcia, że do podjęcia uchwały doszło wskutek poddania pod głosowanie decyzji o udzieleniu absolutorium i nieuzyskania bezwzględnej większości głosów za taką uchwałą.

W praktyce nieudzielenie absolutorium najczęściej następuje po odwołaniu piastuna z organu spółki. Tym samym, w świetle uchwały SN z 1 marca 2007 roku sytuacja procesowa aktualnych i byłych funkcjonariuszy spółki znacząco się różni ${ }^{41}$. Aprobata stanowiska o utracie przez byłych członków organów spółki legitymacji do zaskarżania uchwał prowadzi do pozbawienia ich możliwości doprowadzenia do wyeliminowania kwestionowanej uchwały z obrotu prawnego. Takiego skutku nie zapewnia bowiem skorzystanie z instrumentów ochrony dóbr osobistych.

W ramach analizy dopuszczalności zaskarżania uchwał w przedmiocie absolutorium przez byłych funkcjonariuszy spółki istotnym argumentem pozostaje również oddziaływanie skwitowania na sferę odpowiedzialności cywilnoprawnej członka organu. Choć skutki prawne uzyskania absolutorium budzą kontrowersje w doktrynie, to przeważa pogląd, że zwalnia ono piastuna z odpowiedzialności odszkodowawczej wobec spółki (przynajmniej w określonych granicach), wywołuje zatem skutki zewnętrzne poza spółką ${ }^{42}$.

Niektórzy przedstawiciele doktryny uważają jednak, że absolutorium stanowi tylko akt wewnętrzny spółki, który nie wpływa na jej roszczenia odszkodowawcze wobec piastuna organu. Nie uwalnia zatem jego członków od odpowiedzialności. Wskazuje się przy tym, że za takim postrzeganiem absolutorium przema-

39 D. Opalska, Problematyka dóbr osobistych w spółkach kapitałowych — zagadnienia wybrane, „Studia Prawa Prywatnego” 2012, nr 3-4, s. 53; M. Śledzikowski, Skutki prawne udzielenia absolutorium dla członków zarządu spółki z ograniczona odpowiedzialnościa, Warszawa 2018, s. 200.

40 S. Sołtysiński, Glosa do wyroku SN z 13 lutego 2004 r., II CK 438/02, „Orzecznictwo Sądów Polskich" 2006, nr 5, poz. 53.

41 D. Opalska, op. cit., s. 53-54.

42 Tak między innymi M. Romanowski, Znaczenie prawne absolutorium w spółce kapitałowej, „Przegląd Prawa Handlowego” 2002, nr 4, s. 12-13; R. Pabis, Prawny charakter absolutorium udzielanego członkom organów spółki kapitałowej, „Monitor Prawniczy” 2005, nr 1, s. 17. 
wia między innymi praktyka odwoływania go ${ }^{43}$. Akceptacja takiego stanowiska pozwala przyjąć, że nie ma uzasadnienia przyznanie byłym członkom organów spółki prawa do zaskarżania uchwał wspólników o nieudzieleniu absolutorium jako szczególnie istotnych $\mathrm{z}$ punktu widzenia ich sytuacji prawnej wobec spółki $\mathrm{i}^{44}$.

Nie sposób podzielić jednak takiego poglądu. Abstrahując od charakteru absolutorium, samo pozbawienie możliwości dochodzenia podjęcia w tej sprawie niewadliwej uchwały narusza prawa byłych funkcjonariuszy spółki. Na ochronę zasługuje bowiem interes byłego członka organu w przypadku, gdy dąży on do zaskarżenia uchwały bezzasadnie odmawiającej mu udzielenia absolutorium. W spółkach działających na rynku nadzorowanym przez Komisję Nadzoru Finansowego nieudzielenie absolutorium (bez względu na przyczynę) pozbawia w istocie możliwości zasiadania w zarządzie spółki ${ }^{45}$. Wskazanie na dopuszczalność dochodzenia roszczeń na gruncie przepisów o naruszeniu dóbr osobistych nie rozwiązuje tego problemu. Jak słusznie konstatował SN w wyroku z 15 grudnia 2005 roku ${ }^{46}$, ,jest ze wszech miar pożądane, aby uchwała godząca w dobra osobiste w przedmiocie udzielenia absolutorium, mogła zostać wyeliminowana w drodze powództwa z art. 252 k.s.h. Możliwość tę powinny mieć wszystkie osoby poddane procedurze udzielania absolutorium, także więc byli członkowie zarządu lub rady nadzorczej niebędący wspólnikami”"

\section{PODSUMOWANIE}

Ustawodawca umożliwił konkretnym podmiotom wnoszenie powództw o uchylenie lub stwierdzenie nieważności uchwał wspólników spółek kapitałowych z uwagi na potrzebę ochrony określonych interesów. Wyposażenie zarówno samych organów spółek kapitałowych, jak i ich indywidualnych członków w legitymację do zaskarżania decyzji wspólników pozwala na skuteczne eliminowanie z obrotu uchwał sprzecznych z ustawą, umową spółki i dobrymi obyczajami. Tym samym realizowany może być zarówno interes samej spółki i jej wspólników, jak również zapewniane bezpieczeństwo i pewność obrotu gospodarczego.

Przyznając organom spółki zdolność do występowania z powództwem przeciwko spółce, przepisy art. $250 \mathrm{i}$ art. $422 \S 2$ k.s.h. nie normują jednak sposobu ich działania w takiej roli. Zważywszy na to, że skarżąc uchwałę wspólników,

43 K. Bilewska, Byty menedżer nie musi chronić swoich praw skargami korporacyjnymi, „Monitor Prawniczy” 2009, nr 23, s. 1275.

${ }^{44}$ K. Bilewska, Zaskarżanie uchwat zgromadzenia..., s. 1103.

45 D. Opalska, op. cit., s. 52; S. Sołtysiński, Brak skwitowania nie powinien obciążá na wieczność, Rzeczpospolita z 5 listopada 2008 roku.

46 Wyrok SN z 15 grudnia 2005 roku, II CSK 19/05, LEX nr 371799. Podobnie: wyrok SN z 13 lutego 2004 roku, II CK 438/02, OSP 2006/5/53 i wyrok SN z 25 listopada 2004 roku, III CK 592/03, LEX nr 182098; wyrok SA we Wrocławiu z 16 stycznia 2007 roku, I ACa 1461/06, LEX nr 232749. 
organ nie działa w imieniu spółki, a korzysta z przyznanego mu autonomicznego uprawnienia, należy przyjąć, że zasady ogólnej reprezentacji, nie znajdują tu zastosowania.

Jeśli uchwałę zaskarża członek organu spółki, to jego legitymacja nie powinna być uzależniona od statusu funkcjonariusza spółki w dacie wyrokowania, a w chwili podejmowania uchwały i ewentualnie wniesienia samego powództwa. Choć na gruncie dyspozycji art. $250 \mathrm{i}$ art. $422 \S 2$ k.s.h. brak jest podstaw do ustalania kręgu podmiotów zainteresowanych zaskarżeniem uchwały w powiązaniu do jej treści ${ }^{47}$, to przyjęcie, że byli funkcjonariusze spółki są w ogóle pozbawieni legitymacji do zaskarżania uchwał wspólników — nawet tych, które ściśle dotyczą ich interesów osobistych - jawi się jako rozwiązanie, które trudno uznać za zapewniające właściwy standard ochrony. Nie zmienia tego konstatacja, że osoba, której mandat wygasł, może zaskarżyć uchwałę o swoim odwołaniu oraz taką, która narusza jej dobra osobiste, będąc jednocześnie wspólnikiem spółki ${ }^{48}$.

Mając świadomość, że przyjęcie prawa do nieograniczonego kwestionowania uchwał przez byłych członków organów mogłoby skutkować stanem niepewności co do istotnych decyzji w spółce, kierując się wykładnią funkcjonalną należałoby jednak dopuścić uprawnienie byłych funkcjonariuszy w odniesieniu do tak newralgicznych uchwał, jak odwołująca z funkcji oraz nieudzielająca skwitowania. Tym bardziej, że w praktyce uchwałę o nieudzieleniu absolutorium często poprzedza właśnie uchwała o odwołaniu z organu spółki. Przyjęte w tej kwestii odmienne stanowisko Sądu Najwyższego (odmawiające takiej legitymacji) w niewystarczającym stopniu uwzględnia następstwa stosowania teorii cywilistycznych w uwarunkowaniach współczesnego obrotu gospodarczego ${ }^{49}$. Aprobując pogląd, iż cel instytucji zaskarżania uchwał wspólników został podyktowany potrzebą ochrony interesów spółki i jej wspólników, przyjąć jednak należy, że spółka zawsze powinna mieć interes prawny w wyeliminowaniu wadliwej uchwały.

\section{THE RIGHT OF COMPANY'S GOVERNING BODIES AND THEIR INDIVIDUAL MEMBERS TO APPEAL RESOLUTIONS ADOPTED BY MEETINGS OF CAPITAL COMPANIES' SHAREHOLDERS}

Summary

The legislator granted the right to appeal shareholders' resolutions to both — company's governing bodies and their individual members. The Commercial Companies Code, however, does not specify the rules for taking action of this kind by the management board, the supervisory board, the board of directors, the audit committee, or the circle of authorized members of these bodies. The main purpose of the article is to determine when the entitlement of company's officers to appeal

47 M. Śledzikowski, op. cit., s. 173.

48 B. Ostrzechowski, op. cit., s. 38.

49 A. Opalski, op. cit., s. 39. 
against shareholders' resolutions expires. Due to the ratio legis of the analyzed provisions, it is necessary to assume that a member of the governing body retains the right to support their action even after losing his status. The position of the Supreme Court denying a former company officer the legitimacy to appeal against a resolution on their dismissal and a resolution not to grant them discharge should also be regarded as not providing an adequate level of protection.

Keywords: commercial law, commercial companies, Supreme Court case law, challenging resolutions, action for setting aside or invalidating a resolution

\section{BIBLIOGRAFIA}

Bieniak J. et al., Kodeks spótek handlowych. Komentarz, Warszawa 2020.

Bilewska K., Były menedżer nie musi chronić swoich praw skargami korporacyjnymi, „Monitor Prawniczy" 2009, nr 23.

Bilewska K., Naruszenie dóbr osobistych w uchwale walnego zgromadzenia dotyczacej absolutorium, „Palestra” 2006, nr 7-8.

Bilewska K., Zaskarżanie uchwat zgromadzenia wspólników przez odwołanych członków organów spótki. Glosa do uchwały SN (7) z 21.3.2007 r., III CZP 94/06, „Monitor Prawniczy” 2007, nr 19.

Czajkowska-Dąbrowska M., Konsekwencje sprzeczności z prawem uchwał zgromadzeń wspólników spótek kapitałowych ze szczególnym uwzględnieniem legitymacji bylych członków organów spótek do zaskarżania tych uchwał, [w:] Studia i analizy Sądu Najwyższego, red. K. Ślebzak, t. 1, Warszawa 2007.

Draniewicz B., Legitymacja do wytoczenia powództwa przeciwko spótce. Glosa do uchwaty SN z 17.02.2004 r., III CZP 116/03, „Prawo Spółek” 2005, nr 5.

Gierat P., Zaskarżanie uchwał zgromadzeń spółek kapitałowych przez ich organy oraz przez członków tych organów, „Monitor Prawniczy” 2008, nr 13.

Jarocha A., Powództwo o stwierdzenie nieważności uchwały wspólników spótki kapitałowej, Toruń 2010.

Jurcewicz W., Legitymacja czynna członków władz spółki do zaskarżenia uchwał zgromadzenia wspólników. Glosa do uchwaty składu siedmiu sędziów SN z 1.03.2007 r., III CZP 94/06, „Glosa” 2008, nr 1.

Jurcewicz W., Zaskarżanie uchwat przez odwołanych członków zarządu spótki. Glosa do wyroku SN z 11.01.2002 r., IV CKN 1503/00, „Przegląd Prawa Handlowego” 2003, nr 3.

Kidyba A., Kodeks spótek handlowych, t. 1. Komentarz do art. 1-300 k.s.h., Warszawa 2013.

Kodeks spótek handlowych, t. 2B. Spótka z ograniczoną odpowiedzialnościa. Komentarz. Art. 227300, red. A. Opalski, Warszawa 2018.

Kodeks spótek handlowych. Komentarz, red. Z. Jara, Warszawa 2020.

Kodeks spótek handlowych. Komentarz, t. 3, red. T. Siemiątkowski, R. Potrzeszcz, Warszawa 2013.

Kuniewicz Z., Glosa do wyroku SN z 11 stycznia 2002 r., IV CKN 1503/00, Orzecznictwo Sądów Polskich 2003, nr 2, poz. 21.

Kwaśniewski Z., Zaskarżanie uchwał zgromadzeń spółek kapitałowych — problem legitymacji czynnej, [w:] Kodeks spótek handlowych po pięciu latach, red. L. Banel, U. Gączkowska, Wrocław 2006.

Marszałkowska-Krześ E., Jagodziński M., Występowanie organów spótek kapitałowych na podstawie przepisów przyznających szczególna zdolność sądowa w sprawach o zaskarżenie uchwat zgromadzeń tych spótek - rozważania de lege lata oraz de lege ferenda, [w:] Kodeks spótek handlowych po piętnastu latach obowiazywania, red. J. Frąckowiak, Warszawa 2018. 
Opalska D., Problematyka dóbr osobistych w spółkach kapitałowych — zagadnienia wybrane, „Studia Prawa Prywatnego” 2012, nr 3-4.

Opalski A., Kodeks spótek handlowych w ostatnich latach — tendencje w orzecznictwie sadowym, [w:] Kodeks spótek handlowych po dziesięciu latach, red. J. Frąckowiak, Wrocław 2013.

Ostrzechowski B., Naruszenie czci w wyniku nieudzielenia absolutorium w spótce kapitałowej, „Przegląd Prawa Handlowego" 2018, nr 8.

Pabis R., Prawny charakter absolutorium udzielanego członkom organów spółki kapitałowej, „Monitor Prawniczy" 2005, nr 1.

Pęczyk-Tofel A., Legitymacja czynna na gruncie art. 250 i art. 422 \& 2 k.s.h., „Prawo Spółek” 2007, nr 10.

Rodzynkiewicz M., Kodeks spótek handlowych. Komentarz, Warszawa 2013.

Romanowski M., Absolutorium w spółce kapitałowej, „Przegląd Prawa Handlowego” 2002, nr 1.

Romanowski M., Znaczenie prawne absolutorium w spółce kapitałowej, „Przegląd Prawa Handlowego" 2002, $\mathrm{nr} 4$.

Skrodzka M.J., Skrodzki K., Legitymacja czynna byłego członka zarządu spółki z o.o. do zaskarżenia uchwat wspólników - w świetle poglądów doktryny i orzecznictwa, „Monitor Prawniczy” 2007, nr 19.

Sołtysiński S. et al., Kodeks spótek handlowych, t. 2. Komentarz do artykułów 151-300, Warszawa 2014.

Sołtysiński S. et al., Kodeks spółek handlowych, t. 3. Komentarz do artykułów 301-490, Warszawa 2013.

Sołtysiński S., Brak skwitowania nie powinien obciążá na wieczność, „Rzeczpospolita” 5.11.2008.

Sołtysiński S., Glosa do wyroku SN z 13 lutego 2004 r., II CK 438/02, Orzecznictwo Sądów Polskich 2006, nr 5, poz. 53.

Sołtysiński S., Popiołek W., Legitymacja czynna odwołanych członków władz spółki do zaskarżenia uchwat sprzecznych z ustawa, „Przegląd Prawa Handlowego” 2007, nr 10.

Śledzikowski M., Skutki prawne udzielenia absolutorium dla członków zarządu spółki z ograniczona odpowiedzialnościa, Warszawa 2018.

Wajda D., Naruszanie dóbr osobistych członków organów spótek kapitałowych uchwała zgromadzenia dotyczaca absolutorium, „Przegląd Prawa Handlowego” 2018, nr 11. 